\title{
Shifting Hazards: Footprint trends of the German Bioeconomy
}

\section{Stefan Bringezu ( $\nabla$ bringezu@uni-kassel.de )}

University of Kassel https://orcid.org/0000-0001-8745-984X

\section{Martin Distelkamp}

Institute of Economic Structures Research (GWS)

Christian Lutz

Institute of Economic Structures Research (GWS)

\section{Florian Wimmer}

Center for Environmental Systems Research - Kassel University

\section{Rüdiger Schaldach}

Universitat Kassel, Center for Environmental Systems Research, Kassel, Germany

\section{Klaus Hennenberg}

Ökoinstitut

Hannes Böttcher

Öko-Institut

Vincent Egenolf

Center for Environmental Systems Research - Kassel University

\section{Article}

Keywords: Biomass Use, Land Use Change, Water Stress, Climate Footprint

Posted Date: November 13th, 2020

DOl: https://doi.org/10.21203/rs.3.rs-105359/v1

License: (c) (1) This work is licensed under a Creative Commons Attribution 4.0 International License.

Read Full License 


\section{CONFIDENTIAL}

2 Manuscript submitted to NATURE Sustainability

$9^{\text {th }}$ Nov 2020

4

\section{Shifting Hazards: Footprint trends of the German Bioeconomy}

\section{Abstract}

8 Hoping to support sustainability, many countries established policies to foster bioeconomy

9 (BE). While shifting towards more biomass use bears chances and risks, appropriate

10 monitoring is still lacking. Here we show for the first time global key environmental

11 footprints (FPs) of the German BE. From 2000 to 2030, the agricultural biomass FP is

12 dominated by animal-based food consumption, which is slightly declining. Forest biomass FP

13 of consumption could be potentially supplied from domestic territory. Agricultural land use

14 for consumption is triple of domestic agricultural land (which covers half of Germany),

15 having induced significant land use change in other regions from 2000 to 2015. Water FP for

16 irrigation has decreased and might decline in absolute terms, but the share of supply regions

17 with water stress might increase until 2030. The climate FP of BE contributes 20 to $18 \%$ to

18 the total climate FP of domestic consumption, while employment makes up $10 \%$ and value

19 added only $8 \%$ of total. 


\section{Introduction}

Still, many believe in a basic misconception: biomass is renewable and its use would generally be sustainable. In the past decades, several countries like USA, Sweden and Germany, as well as the European Union and the OECD have established policies to foster a shift towards a bioeconomy $(\mathrm{BE})^{1,2}$. The intention was mainly to substitute fossil and mineralbased resources by biomass, and there have been high hopes in additional income of farmers and foresters through bioenergy and biomaterials, sustaining rural development, and economic growth through innovations in biotechnology ${ }^{3}$. As a consequence of increased use of biomass, however, unwanted side-effects turned out, such as land use change, directly or indirectly induced by growing demand for both food, fibres and fuels, leading to an overexploitation of biotic resources, water and land domestically and internationally ${ }^{4,5}$ losses of biodiversity ${ }^{6}$ and to an overcompensation of GHG savings by biofuels ${ }^{7}$. It has become clear, meanwhile, that any BE would only be sustainable when following important principles $^{8}$, and when balanced against critical thresholds of global sustainable resource use $^{9,10}$. BE strategies are now being directed towards a more circular economy with higher resource efficiency ${ }^{11,12}$.

While policy strategies have been implemented and billion dollar heavy industries such as on biofuels have been created, a comprehensive monitoring of the actual performance of BE regarding the achievement of sustainability goals, including the effects of past and ongoing policies has been largely lacking ${ }^{13,14}$. Requirements and concepts for bio-economy monitoring are discussed for example by O'Brien et al. ${ }^{15}$ and Robert et al. ${ }^{16}$. In this context resource FPs are seen as suitable indicators to assess the environmental effects of human consumption (e.g. Tukker et al. $\left.{ }^{17}\right)$.

In this article, we provide for the first time a comprehensive analysis of past and projected resource and climate FPs of the German BE and relate them to its socio-economic 
47

performance. Building on conceptual ${ }^{15,18}$ and empirical ${ }^{17,19}$ work, we concentrate on the material (forest and agricultural biomass), agricultural land, water and climate FPs as an essential part of a future monitoring system. FPs were calculated for the historic period from $2000-2015$ and for a trend projection until the year 2030.

\section{Findings}

The environmental FPs of the German BE have been determined on the basis of global, lifecycle-wide requirements of fully or partly biomass-based products annually produced and consumed in Germany, for agricultural raw materials (agriculture biomass FP), primary timber (forestry biomass FP), agricultural land (land FP), irrigation water (water FP), and greenhouse gas $(G H G)$ emissions (climate FP). The FPs of the German BE account for the global pressures of total supply, comprising domestic production plus imports; those of exports are deducted when measuring FPs of domestic consumption. The environmental FPs are complemented by socio-economic indicators of value added and employment.

\section{Agricultural biomass footprint}

In 2015, Germany harvested 214 Mt of agricultural biomass on own territory. The trade balance for directly traded agricultural products revealed an import dependency (31 Mt imports vs. 19 Mt. exports). Considering the FPs of imports and exports, that dependency becomes more pronounced, with direct and indirect flows of biomass accounting $311 \mathrm{Mt}$ for imports vs. $110 \mathrm{Mt}$ for exports. One reason for these massive differences in magnitude is that fodder crops and crop residues are seldom directly traded but indirectly in form of the products made from the fed animals.

In 2015, the agricultural biomass FP of consumption amounted to $5.0 \mathrm{t} /$ person and exceeded the global average of $2.8 \mathrm{t} /$ person by $81 \%$ (Figure 1a). When ongoing trends of shifts in 
dietary patterns like a slightly decreasing meat consumption in Germany are projected to continue to 2030 the exceedance may decrease to below $50 \%$.

Globally about $40 \%$ of harvested agricultural biomass is used in the form of grains or other primary crops, while $60 \%$ is being grazed or used as crop residues, fodder or energy crops. This predominance of biomass for feed (and energy) purposes upon biomass for food (and clothing) purposes can also be observed for Germany's agricultural biomass FP with a share of grains and other primary crops of 43 to $45 \%$ in the reporting period. Cereal grains contribute one third to the primary crops used, and about $60 \%$ of the cereals produced or imported are being used as feed ${ }^{20}$. Thus, the major part of harvested agricultural biomass is used for animal production.

\section{Forestry biomass footprint}

Germany is a net importer of roundwood equivalents (RE) (Fig. 1b). The forest FP of domestic consumption exceeded domestic roundwood production by about $45 \%$ on average from 2000 to 2015. The past level of the consumption FP of $95.1 \mathrm{Mm}^{3} \mathrm{RE}$ on average could have been completely supplied from domestic territory as it lay within the bandwidth which outlined the potential of sustainable national roundwood production ranging from 86 to 114 $\mathrm{Mm}^{3} \mathrm{RE}$ in 2015 to 79 to $118 \mathrm{Mm}^{3} \mathrm{RE}$ in $2030^{21}$. For exports, ongoing trends would lead to rising volumes up to $32 \mathrm{Mm}^{3} \mathrm{RE}$ until 2030. Then, the total demand for RE for the domestic production would reach a level which could no longer be supplied from own territory only.

The average German consumption of RE has been $1.17 \pm 0.06 \mathrm{~m}^{3} /$ person, thus not exceeding $1.25 \mathrm{~m}^{3} /$ person, a value which had been proposed for safe and just maximum roundwood consumption considering the productivity of European forests ${ }^{22}$. Globally, the average consumption of RE is significantly lower than Germany's (Fig. 1b) as many regions are void 
of forests and use other materials instead. Thus, with regard to availability and productivity, a comparison seems more adequate with European forests.

\section{Land footprint}

Germany uses triple of domestic agricultural land globally to supply its consumption. In 2015, the land FP was 51 Mha, compared to 17 Mha of domestic agricultural area. The land FP might decrease in the coming years, if ongoing trends of reduced meat consumption were to continue (Fig. 1c). German land FP of consumption would fall below global per person average; however, cropland use - which is the most intensive form of agricultural land use might still be beyond average in 2030 (Fig. 2a), and would also exceed the 0.20 ha/person which had been suggested as proxy safe operating space ${ }^{23}$.

The increased biomass consumption in Germany in the early 2000s had not only led to land use per person above global average. It significantly contributed also to land transformation, primarily in other regions of the world (Fig. 2b). Whereas global average annual transformation rate between 2000 and 2015 fluctuated between 19 to $22 \mathrm{~m}^{2} /$ person (Fig. 2c), the German induced foreign land use change per year started with $90 \mathrm{~m}^{2} /$ person in the period 2000-2005, decreased to $32 \mathrm{~m}^{2} /$ person in 2015 and might go down to zero until 2030. This indicates that Germany had exerted its major pressure towards global land use change and loss of natural habitats due to its increases in biomass demand - which was higher than yield increases - in past decades. From 2000 to 2005 mainly forest was converted to agricultural land, while from 2010 onward mainly used grassland was transformed for more intensive uses. Land conversion and intensification might have been associated with loss of biodiversity.

Projection data on future development are uncertain, not only because of the not yet considered Covid-19 impact, but also due to variation of yield increase, assumptions on 
118 development of built-up land and rewetting of fields on former peatland, and varying

119 substitution of imports by domestic production. As consequence, in 2030, land FP of German

120 BE production could range +/- 14 to $15 \%$ around a medium 45 Mha. Medium Land FP of

121 consumption would be 37.6 Mha and range $-12 \%$ to $+15 \%$ (Table 1 ).

122

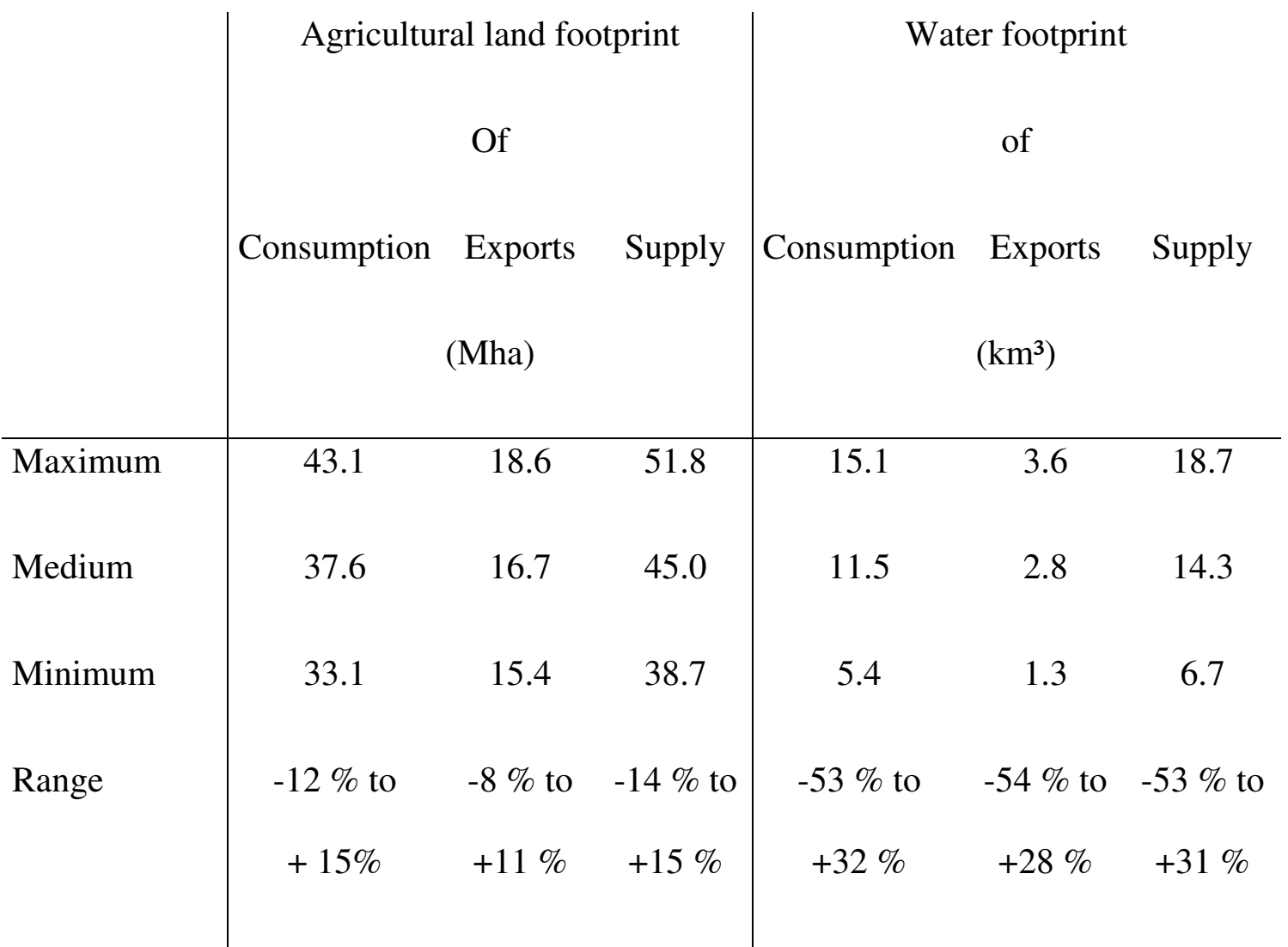

123 Table 1. Variation of agricultural land footprint and water footprint projected for 2030 for

124 domestic consumption, export, and total supply (domestic production plus imports). Medium:

125 projection of current trends. Minimum: compared to ongoing trend $+20 \%$ higher yield

126 increases; -20 \% lower rate for new built-up areas; -34 \% lower rate for rewetting of organic

127 soils. Maximum: compared to ongoing trends $-20 \%$ lower yield increases; $+20 \%$ higher rate

128 for new built-up areas; $+34 \%$ higher rate for rewetting of organic soils. 
131 The water FP for domestic consumption of agricultural goods comprises annual irrigation

132 water withdrawals, mainly in foreign regions (98\%). While ongoing trends indicate that, as a

133 consequence of climate change, global irrigation water withdrawals might grow by up to $21 \%$

134 from 2015 to 2030 , the German water FP is expected to decline by $28 \%$ (from $15.8 \mathrm{~km}^{3}$ to

$13511.5 \mathrm{~km}^{3}$ ) mainly due to changing import structure. On a per-person basis, global irrigation

136 water withdrawals might slightly decline from 2015 to 2030 from 263 to $226 \mathrm{~m}^{3} /$ person, while

137 the German water FP will decrease from $192 \mathrm{~m}^{3} /$ person to $138 \mathrm{~m}^{3} /$ person) (Fig. 1d).

138 Varying material flows of different primary crops both unprocessed and embedded in

139 consumed products have led to changes in the composition of the water FP (Fig. 3). In 2000,

140 the water FP attributable to the consumption of products based on cotton made up for $31 \%$ of

141 the total water FP, followed by wheat (22\%), paddy rice (13\%), and vegetables/fruits/nuts

142 (11\%). By 2015, the share of cotton was halved (14\%), while the contribution of

143 vegetables/fruits/nuts doubled (22\%). Contributions by remaining crops show comparably

144 small variations in relative terms. In absolute terms, the reduction of the water FP from 20.4

$145 \mathrm{~km}^{3}$ in 2000 to $15.8 \mathrm{~km}^{3}$ in 2015 equals roughly the decline in the water FP of cotton-based

146 products $\left(4.1 \mathrm{~km}^{3}\right)$. By 2030, paddy rice is projected to contribute most to the water FP

147 (24\%), followed by vegetables/fruits/nuts (23\%), wheat (17\%), and cotton (10\%).

148 Global irrigation water withdrawals afflicted with water stress per person are found to

149 decrease from $125 \mathrm{~m}^{3}$ to $101 \mathrm{~m}^{3}(-19 \%)$ between 2000 and 2030 . The part of the German

150 water FP stemming from water-stressed regions might decrease from 96 m³/person to 60

$151 \mathrm{~m}^{3} /$ person $(-37 \%)$ in the same period. Hence, the pressure on water resources per person

152 induced by Germany's consumption of embodied irrigation water is less than the global

153 average and is projected to decline. 
154 The source regions of three quarters of the water FP afflicted with water stress in 2015 are

155 located in the Middle East (35\%), Central and South-East Asia (25\%), and China (16 \%). In

156 these regions, up to $2 \%$ of their total irrigation water withdrawals from regions with high

157 water stress are attributable to Germany's consumption.

158 In the Middle East, irrigation of vegetables/fruits/nuts (52\%), wheat (17\%), and oil seeds

$159(10 \%)$ contributes most to the water FP afflicted with water stress. Large parts of the Middle

160 East suffer from high water stress, resulting in $61 \%$ of water withdrawals for

161 vegetables/fruits/nuts, $57 \%$ for wheat, and $79 \%$ for oilseeds occurring in regions with high

162 water stress. Irrigation of wheat (35\%), paddy rice (31\%), and cotton (16\%) dominate the

163 water FP connected to water stress in South East and Central Asia. In China, irrigation of

164 cotton (39\%), wheat (26\%), and paddy rice (15\%) contributes most.

165 Main sources of uncertainties of the projections of water FP are from land use projections and

166 variations of assumed water intensity of yield changes. Thus, the range of potential variation

167 of the water FP in 2030 is higher than for land (Tab. 1).

\section{Climate footprint}

169 Compared to world average the German BE contributions to total domestic GHG emissions

170 covered by the UN Framework Convention on Climate Change are rather low (11-12\% in

171 Germany vs. 17-18 \% in the world). However, when looking at the climate FP, the picture

172 changes. In -2015 , the BE climate FP of German consumption amounted to $1.9 \mathrm{t} \mathrm{CO}_{2}$ eq per

173 person and thus substantially exceeded the global average of slightly above $1 \mathrm{t}$ per person

174 (Figure 1e). More than half of this climate FP consists of emissions on foreign territories (and

175 therefore are not covered by Germany's NDCs under the Paris Agreement).

176 With continuing past trends, the BE's domestic emissions will only be reduced slightly, by

$17713 \%$ from 2000 to 2030 , much less than the expected reduction of the FP of total 
consumption (-37 \%). Nevertheless, it is expected that in 2030 Germany's total climate FP will still exceed the domestic GHG emissions of the BE by a factor of more than 1.5. The BE climate FP of German exports substantially increased in the recent past (from $750 \mathrm{~kg}$ per person in 2000 to about $900 \mathrm{~kg}$ per person today) and may be expected to grow slightly until 2030.

While for the economy as a whole and also its total climate $\mathrm{FP} \mathrm{CO}_{2}$ emissions contribute more than $75 \%$, a BE-specific analysis of domestic emissions and FPs shows a balanced contribution of three greenhouse gases: $\mathrm{CO}_{2}, \mathrm{CH}_{4}$ and $\mathrm{N}_{2} \mathrm{O}$ indicating the relevance of ruminant farming and fertilizer management on the fields, resp.

Crop farming, livestock farming and other BE activities contribute $30 \%, 46 \%$ and $23 \%$, resp., to global average climate FP of the BE. For the German BE's climate FP of consumption the portions are rather similar (28\%, $44 \%$ and $28 \%$, resp., in 2015). For the contribution of livestock farming a further slight decline to $43 \%$ in 2030 may be expected, if current trends are prolonged to the future.

Within the total German economy, the contribution of BE to territorial GHG emissions was $11.9 \%\left(-108 \mathrm{Mt} \mathrm{CO}_{2} \mathrm{eq}\right)$ in -2015 . At the same time the contribution of BE climate FP to the total climate FP of consumption was $15.2 \%$ (160 Mt CO $2 \mathrm{eq})$. Until 2030, without further policy action, the climate $\mathrm{FP}$ of $\mathrm{BE}$ is expected to decline less pronouncedly than the climate FP of the whole German economy. With implementation of the climate action programme $2030^{24}$ the BE share will probably even be higher.

\section{Value added and employment by $B E$}

There had been high hopes linked with bio-based transformation of the economy which has been seen as the future foundation of economic growth ${ }^{1,2}$. Indeed, there has been a certain growth of for the German BE from 222 billion EUR 2015 in 2000 to 248 billion EUR in 2015, 
and until 2030 one may expect further increase to 316 billion EUR2015. Measured in Purchaser

203 Power Parities (PPP), the BE contribution to value added per person in Germany is nearly

204 twice as high as on global average. However, this portion represents about 8 to $9 \%$ of total

205 value added generated in Germany, compared to 14 to $16 \%$ global average, and these shares

206 might not increase until 2030.

207 The contribution of the BE to employment in Germany (10\% to $12 \%$ ) is slightly higher than 208 to value added. Globally, in 2015 still more than one third of all persons engaged could be 209 attributed to the BE. Looking at the BE related socio-economic FPs (Fig. 1f,g) shows that 210 Germany is as generous in spreading benefits from the BE around the world as it is regarding 211 environmental burden. On average every consumer in Germany contributes to BE value added 212 somewhere around the world in the order of 2000 to 2500 PPP int. \$2011. At the same time 213 about $0.2 \mathrm{BE}$ persons engaged in other countries can be attributed to the average consumer in 214 Germany, while within the country it is less than 0.04 BE persons.

215 Crop farming and livestock farming contribute the lowest share to value added and remain on 216 a rather low level. Even negative dynamics in price-deflated value added can also be observed 217 in some other old-established parts of BE (e.g. forestry and fishery and manufacturing of food $218 \&$ beverages or textiles) and are contrasted by innovative or dynamic BE parts (e.g.

219 manufacturing of bio-based chemicals or restaurant services) that showed above average 220 growth rates in the last decades.

221 It must be taken into account that contributions of new branches such as biotechnology and 222 their products until now cannot be measured sufficiently well. One may expect, nevertheless, 223 that in future combinations of biomass- and mineral-based processes will be used, and the 224 degree to which natural resources can be used efficiently will determine both environmental 225 and economic competiveness leading to further growth. 
This article provides a synopsis of key indicators of the German BE with a focus on global environmental FPs. It shows that the territorial perspective needs to be complemented by a transnational perspective. In terms of sustainability, a first orientation on whether a country exerts disproportionate pressure is possible by comparing FP levels with global or continental average.

On a per person basis, agricultural biomass consumption of Germany exceeds global average; consumption of primary timber is at a level which can be supplied sustainably at European scale; agricultural land use has exceeded global average in the past, and cropland use may still be beyond average and sustainable levels in 2030 without additional measures. In particular,

235 climate FP of German BE is disproportionally high, also in relation to the rather moderate 236 contribution to socio-economic performance.

\section{References}

239 1. De Besi, M., \& McCormick, K. Towards a bioeconomy in Europe: National, regional $240 \quad$ and industrial strategies. Sustainability 7(8), 10461-10478 (2015).

241 2. Meyer, R. Bioeconomy Strategies: Contexts, Visions, Guiding Implementation Principles 242 and Resulting Debates. Sustainability 9, 1031 (2017).

243 3. D'Amato, D. et al. Green, circular, bio economy: A comparative analysis of sustainability 244 avenues. Journal of Cleaner Production 168, 716-734 (2017).

245 4. Bringezu, S., O’Brien, M., Schütz, H. Beyond Biofuels: Assessing global land use for 246 domestic consumption of biomass. A conceptual and empirical contribution to 247 sustainable management of global resources. Land Use Policy 29(1), 224-232 (2012). 
5. Brizga, J., Miceikiene, A., Liobikiene, G. Environmental aspects of the implementation of bioeconomy in the Baltic Sea Region: An input-output approach. Journal of Cleaner Production 240, 118238 (2019).

6. Immerzeel, D.J., Verweij, P.A., van der Hilst, F., Faaij, A.P.C. Biodiversity impacts of bioenergy crop production: a state-of-the-art review. GCB Bioenergy 6, 183-209 (2014).

7. Valin, H. et al. The land use change impact of biofuels consumed in the EU: Quantification of Area and Greenhouse Gas Impacts. ECOFYS Netherlands B.V. (2015).

8. FAO. ( FAO, accessible under http://www.fao.org/faostat/en/\#data/QC, downloaded 12/2019, (2019).

9. Steffen, W. et al. Planetary boundaries: Guiding human development on a changing planet. Science 347, 6223 (2015).

10. Bringezu, S. Toward Science-Based and Knowledge-Based Targets for Global Sustainable Resource Use. Resources 8, 140 (2019).

11. D'Amato, D., Korhonen, J., \& Toppinen, A. Circular, green, and bio economy: how do companies in land-use intensive sectors align with sustainability concepts? Ecological Economics 158, 116-133 (2019).

12. Stegmann, P., Londo, M., Junginger, M. The circular bioeconomy: Its elements and role in European bioeconomy clusters. Resources, Conservation and Recycling: X 6, 100029 (2020).

13. Lier, M. et al. Synthesis on bioeconomy monitoring systems in the EU Member States indicators for monitoring the progress of bioeconomy. Natural resources and bioeconomy studies 38, 44, Natural Resources Institute Finland, Helsinki (2018).

14. Bracco, S., Calicioglu, O., Gomez San Juan, M., Flammini, A. Assessing the Contribution of Bioeconomy to the Total Economy: A Review of National Frameworks. Sustainability 10, 1698 (2018). 
15. O'Brien, M., Wechsler, D., Bringezu, S., \& Schaldach, R. Toward a systemic monitoring of the European bioeconomy: Gaps, needs and the integration of sustainability indicators and targets for global land use. Land Use Policy 66, 162-171 (2017).

16. Robert, N. et al. Development of a bioeconomy monitoring framework for the European Union: An integrative and collaborative approach. New Biotechnology 59, 10-19 (2020).

17. Tukker, A. et al. Environmental and resource footprints in a global context: Europe's structural deficit in resource endowments. Global Environmental Change 40, 171-181 (2016).

18. Egenolf, V. \& Bringezu, S. Conceptualization of an Indicator System for Assessing the Sustainability of the Bioeconomy. Sustainability 11, 443 (2019).

19. Steinmann, Z. J. et al. Resource footprints are good proxies of environmental damage. Environmental science \& technology 51(11), 6360-6366 (2017).

20. Bringezu, S. et al. Pilotbericht zum Monitoring der deutschen Bioökonomie. Center for Environmental Systems Research (CESR), University of Kassel. doi:10.17170/kobra202005131255 (2020).

21. Oehmichen, K., et al. Die alternativen WEHAM-Szenarien: Holzpräferenz, Naturschutzpräferenz und Trendfortschreibung. Szenarienentwicklung, Ergebnisse und Analyse, Thünen Report. Braunschweig. https://doi.org/10.3220/REP1527686002000 (2018).

22. O'Brien, M., Bringezu, S. What Is a Sustainable Level of Timber Consumption in the EU: Toward Global and EU Benchmarks for Sustainable Forest Use. Sustainability 9, $812(2017)$.

23. UNEP. Assessing Global Land Use: Balancing Consumption with Sustainable Supply. A Report of the Working Group on Land and Soils of the International Resource Panel. Bringezu S., Schütz H., Pengue W., O`Brien M., Garcia F., Sims R., Howarth R., Kauppi L., Swilling M., and Herrick J. (2014). 
24. German Government. Key elements of the Climate Action Programme 2030. https://www.bundesfinanzministerium.de/Content/EN/Standardartikel/Topics/Priority$\underline{\text { Issues/Climate-Action/2019-09-19-climate-action-programm- }}$ download.pdf? blob=publicationFile \&v=2 (2019).

\section{Methods}

\section{Input-Output-based footprint analysis}

BE related FPs of supply and consumption (incl. capital formation) as well as those for exports were determined for GHG emissions and resource use (biotic materials, land, water). Total supply FPs comprise emissions/resource use on domestic territory plus those associated with imports. Consumption FP deducts FP of exports from total supply FP $25,26,27$.

In order to trace back imports to the countries of origin (of the raw materials), the global multi-regional input-output data base EXIOBASE was used. Its most recent data set for the assessment of BE related FPs (v3.4) has been released in July 2018 and covers the historical period from 1995 to 2011 on a yearly base $\mathrm{e}^{28,29}$. By assessing the database for monitoring the $\mathrm{BE}$ in Germany some major shortcomings (e.g. regarding the $\mathrm{CO}_{2}$ emissions by agriculture in Germany) have been detected and fixed.

In a first step this corrected historical dataset has been prolonged up to 2017 by means of a now-casting procedure, that translates knowledge on developments in the recent past (20112017) from official statistics into an updating of the whole database. The statistics that have been used in this procedure range from the World Development Indicator database by Worldbank (e.g. for observations on the development of the different GDP components in all countries and rest of world-regions) to the FAO database (e.g. for observations on the production of crops in monetary terms as well as in physical units). 
Projections of future development have assumed continuation of recent trends and have been

324 oriented towards SSP2 $2^{30,31}$. Socio-economic trends stem from $\mathrm{UN}^{32}$ regarding population. For 325 GDP, OECD quantifications have been used ${ }^{33}$. For Germany, we use detailed projection data 326 until 2030 from a long-term trend scenario that has been developed with close feedback from 327 different German public institutions as a basis for the national vulnerability analysis ${ }^{34}$. For 328 updating the data framework of EXIOBASE until 2030 (including not only the MRIO data for 329 the economic supply and use interdependencies, but also satellite data for environmental and 330 socio-economic extensions) we could refer to two inhouse models (PANTA RHEI, 331 GINFORS) that already translated this business-as-usual paradigm and exogenous guidelines 332 into quantitative EE-IO model results from a national perspective as well as from a global, 333 multinational perspective $\mathrm{e}^{35,36,37,38}$.

334 The method for the assessment of BE related FPs by means of an application of global 335 environmentally extended MRIO EXIOBASE can be summarized as follows: the multi336 regional vector of consumption incl. capital formation (= final inlands use of country c 337 diffentiated for products and their countries of origin), is denoted as $m r f i u_{c}$ and the matrix of 338 multi-regional input-output coefficients as MRIOA. This standard repertoire of MRIO analysis 339 in our case is expanded by a number of matrices and vectors. For the following examples 340 these expansions cover:

- $\operatorname{mrexp}_{c} \sim$ multi-regional vector of exports by country c,

342 - MREXI_AGBI a square-matrix with entries on the main diagonal for the extraction 343 intensity of production (in kg per EUR of production) for agricultural biomass,

344 - mrbes $\sim$ a square-matrix with entries on the main diagonal for the bioeconomy share 345 of the respective industry/product

346 - mremi a square-matrix with entries on the main diagonal for the emission intensity of production (in $\mathrm{kg} \mathrm{CO}_{2}$ equivalents per EUR of production) for all $\mathrm{GHG}$ together. 
- mrvai a square-matrix with entries on the main diagonal for the value added intensity of production (in EUR value added per EUR production).

Then the (sum of the multi-regional vector of the) biomass agriculture FP of consumption and capital formation in country c $(\operatorname{mrcfp}[\mathrm{agbi}] \mathrm{c})$ can be calculated as follows:

(1) $C F P_{a g b i}=\sum \operatorname{mrcfp}[a g b i]_{c}=M R E X I \_A G B I * M R B E S *(I-M R I O A)^{-1} *$

The (sum of the multi-regional vector of the) BE related ghg FP of consumption and capital formation in country c $\left(\operatorname{mrcfp}[\mathrm{begh}]_{\mathrm{c}}\right)$ is given by:

(2) $C F P_{b e g h}=\sum \operatorname{mrcfp}[\text { begh }]_{c}=M R E M I * M R B E S *(I-M R I O A)^{-1} * m r f i u_{c}$

The (sum of the multi-regional vector of the) BE related value added FP of consumption and capital formation in country $\mathrm{c}\left(\operatorname{mrcfp}[\text { beva }]_{\mathrm{c}}\right)$ is given by:

(3) $C F P_{\text {beva }}=\sum \operatorname{mrcfp}[\text { beva }]_{c}=M R V A I * M R B E S *(I-M R I O A)^{-1} * m r f i u_{c}$

The respective (sums of the multi-regional vectors) for the FP of exports (efp[agbi], efp[begh]) and efp[beva] are calculated by assessing the multiregional vector of exports instead:

(4) $E F P_{a g b i}=\sum \operatorname{mrefp}[a g b i]_{c}=M R E X I \_A G B I * M R B E S *(I-M R I O A)^{-1} *$ $\operatorname{mrexp}{ }_{c}$

(5) $E_{F P} P_{b e g h}=\sum \operatorname{mrefp}[\text { begh }]_{c}=M R E M I * M R B E S *(I-M R I O A)^{-1} * \operatorname{mrexp}_{c}$

(6) $E F P_{\text {beva }}=\sum \operatorname{mrefp}[\text { beva }]_{c}=M R V A I * M R B E S *(I-M R I O A)^{-1} * \operatorname{mrexp} p_{c}$ 
The material matrix F of Exiobase 3.4 comprises seven forest-biomass related use classes.

370 Three of them exclusively contain forest biomass other than wood and are therefore not of

371 interest for the intended FP calculation in this paper. The remaining four are "coniferous

372 wood - industrial roundwood, coniferous wood - woodfuel, non-coniferous wood - industrial

373 roundwood and non-coniferous wood - woodfuel". In the original version of Exiobase 3.4,

374 the amount of wood in the respective use class and country is taken from the FAO, but

375 converted from $\mathrm{m}^{3}$ to kilotons. In the adapted version of Exiobase used for this analysis, the

376 original FAO values are used for the calculation with the unit $\mathrm{m}^{3}$.

\section{Land-use modelling}

378 The LandSHIFT model ${ }^{39,40}$ was applied to calculate the spatial allocation of agricultural land on a global raster with a spatial resolution of 5arc minutes $(=9 \times 9 \mathrm{~km}$ at the Equator). This included rain-fed and irrigated cropland as well as grazing land. Depending on the simulation year, LandSHIFT operated in two different operation modes, i.e., the "initialisation" and "scenario" mode.

383 For the years 1995, 2000, 2005, 2010 and 2015 a sequence of historical land-use maps were generated in initialisation mode by fusing remote sensing data on land $\operatorname{cover}^{41,42}$ with statistical data from FAOSTAT on the area of crop cultivation and grazing ${ }^{8}$.

For the year 2020, 2025, and 2030 land-use maps were generated in scenario mode by allocating as much crop cultivation and grazing area as needed to reach prescribed quantities of production specific to all crops and livestock. The relation between area and production was established using gridded data on potential yields (cropland) and net primary production of grasslands

390 (livestock grazing) as provided by the LPJmL model ${ }^{43}$. The scenario-mode simulations were

391 based on the patterns of agricultural area resulting from the initialisation in 2015 and driven by 392 trend projections of crop and livestock production. At the start of the scenario simulation, 393 calibration factors to convert potential crop yields into actual crop yields (by crop and country) 
were calculated and applied for subsequent time steps. For livestock grazing, the initial calibration was done by calculating the fixed fraction of livestock that can be fed by the grass production on the grazing area.

397 Crop cultivation differentiates twelve primary crop classes, each under irrigated and rain-fed management. The crop classes generally follow the definition underlying EXIOBASE with the classes paddy rice, wheat, cereal grains nec (not elsewhere classified), plant-based fibres, oil

400 seeds, vegetables/fruits/nuts, sugar cane/sugar beet, and crops nec. Because of their importance 401 for the land and/or water FP, soy beans and oil palm (part of oil crops) as well as cotton (part of plant-based fibres) were modelled separately. In addition, fodder crops were modelled, though under rain-fed management only.

Data on area and production of crops and livestock was taken from FAOSTAT ${ }^{8}$. Harvested area for each crop was converted into physical area under irrigated and rain-fed management using results from $\mathrm{SPAM}^{44}$ for $2005^{45}$ (time steps $\left.1995,2000,2005\right)$ and $2010^{46}$ (2010 and later). The physical area of fodder crops was informed by the area under temporary meadows and pastures from FAOSTAT. Due to a lack of data on production of fodder crops in FAOSTAT, the estimates of grass production in EXIOBASE for 44 countries and 5 "rest-of-the-world" regions were used and, if necessary, downscaled to country level using potential grass production on temporary meadows and pastures as a scaling factor.

\section{Land Footprint}

413 The German agricultural land footprint (land-FP) comprises the cropland and grassland areas 414 used for the production of fully or partly biomass-based products consumed in Germany, both 415 domestically and abroad. For imports to Germany, the regions of origin, the crop groups and 416 their assigment to crop groups are determined on the basis of international trade links covered 417 in EXIOBASE (compare material FP). The global area occupation is also determined and the 418 global and German area occupation per person ${ }^{32}$ is calculated. 
Information on the characteristics of the area occupied is integrated into the agricultural FP,

420 which allows a risk assessment of impacts on biodiversity. Thus, it is assumed that the conversion of (1) primary forest ${ }^{47}$, (2) biodiverse forest, (3) biodiverse grassland, (4) other

422 biodiverse land fusing information on biodiversity ${ }^{48,49}$ with land $\operatorname{cover}^{42},(5)$ peatland ${ }^{50},(6)$ 423 wetlands ${ }^{51}$, (7) forest ${ }^{42}$, (8) unused grassland (grassland types in $\mathrm{CCI}^{42}$ not used for graing by 424 LandSHIFT) and (9) used grassland to arable land is associated with an increased risk for 425 biodiversity (risk areas). In case of overlaps, an area is assigned to the category that is listed 426 first in that order. For areas "in use" such as used arable land (including fallow land) and 427 settlement areas, this risk is estimated to be significantly lower. In the case of grassland, 428 already used grassland is generally assumed to be "in use". A land conversion in protected $429 \operatorname{areas}^{52}$ is excluded from conversion.

430 The land conversion rate is calculated as the rate at which risk areas are converted from the 431 beginning to the end of a time step of five years. The allocation of risk areas in the country of 432 origin takes into account changes in imports to Germany and changes in production in the 433 country of origin (e.g. increased yields). If, for example, imports to Germany do not increase 434 or increase only to the extent of the increase in production in the country of origin, imports to 435 Germany are allocated primarily to land in the "in use" category and subordinate to converted 436 land. Increases in imports that go beyond this are directly allocated to the conversion of risk 437 areas.

\section{Water footprint}

439 The water FP is defined as the irrigation water withdrawals associated with material flows of 440 primary crops to the German BE. Total material flows (=production) were split into flows for 441 domestic consumption (default for the water FP) and exports. Estimates of the water FP were 442 aggregated according to water stress levels in the watersheds where the respective crops are 443 cultivated, based on the land-use modelling results. Material flows, the regions of origin and 
444 their assigment to primary crops were determined on the basis of international trade links covered in EXIOBASE.

446 The calculation of the water FP was done in three steps:

447 (1) Information on crop-specific irrigation water withdrawals was calculated based on the 448 global land-use maps provided by LandSHIFT. For each cell with an irrigated crop type, 449 irrigation water requirements were determined with the CROPWAT model ${ }^{47}$ based on bias450 corrected climate data from the IPSL-CM5A-LR general circulation model for RCP6.0 ${ }^{54}$ as 451 described in Schaldach et al. ${ }^{40}$. In addition, the location of the respective irrigated area was 452 combined with spatial information on regional water stress. Regional water stress in about 453140000 (sub-)basins globally was expressed as the ratio of water withdrawals to availabilty 454 (wta) $)^{55}$ using output on freshwater availability of the WaterGAP model ${ }^{56,57,58,59}$ and estimates 455 of water withdrawals for households, industry ${ }^{60}$ and agriculture representative for year 2005. 456 These values were further grouped into three classes of high (wta $>0.4)$, medium $(0.2<$ wta $\leq$ $4570.4)$, and low $(w \operatorname{ta} \leq 0.2)$ water stress $^{61}$.

458 (2) For every country/region and irrigated crop type, the average IWW needed to produce $1 \mathrm{t}$ 459 of that crop was calculated taking into consideration the aforementioned water stress classes. 460 Then, these water intensities were multiplied by the crop specific material flows.

461 (3) These constributions to the water FP in a given year, specific to a unique combination of 462 source region, water stress level at the source, and primary crop, were summed to the total water 463 FP and its relevant fractions (e.g., water FP associated with a given crop or water FP in regions 464 with high water stress), respectively.

465 The largest source of uncertainty of the modelled irrigation water withdrawals and, hence, the 466 water FP was that the relationship between crop water requirements (CWR) and crop yield 467 was not covered in detail by our modelling approach. Although CWR was modelled as a 
function of climate conditions, the effect of other changes affecting average actual crop

469 yields, e.g. management, fertilizer application, or improved crop varieties, on CWR were

470 neglected. The resulting range of uncertainty was assessed by calculating a maximum and

471 minimum estimate of the water FP. The maximum estimate assumed CWR per unit area

472 changing by the same factor as actual irrigated crop yields at constant efficiency of irrigation

473 systems. The minimum estimate assumed CWR depending on climate conditions only and

474 irrigation efficiency changing by the same factor as irrigated crop yields, while irrigation

475 efficiency was limited to a maximum of 0.9 (10\% losses).

\section{Climate footprint}

477 The climate FP allocates emissions of greenhouse gases, that are measured on a territorial 478 basis to the final users of the products.It is assumed that each unit of GHG emissions has the 479 same effect regardless of where it is emitted, as it contributes equally to global warming. For 480 the ex-post assessment of BE related climate FPs the EXIOBASE database already offers all 481 necessary information:

482 1. The global economic interconnectedness that is reported in the (monetary) MRIO tables

483 2. The dependence of the different industries from biotic inputs (for the determination of BE $484 \quad$ shares)

485 3. The industry-specific emission intensity of production for 6 different greenhouse gases $\left(\mathrm{CO}_{2}, \mathrm{~N}_{2} \mathrm{O}, \mathrm{CH}_{4}, \mathrm{HFC}, \mathrm{PFC}, \mathrm{SF}_{6}\right)$ in $\mathrm{CO}_{2}$ equivalents

487 For the projection overall trends with regard to economic ${ }^{33}$ and emission development ${ }^{30}$ are in 488 line with SSP2 developments on global level and a national reference scenario ${ }^{34}$. Structural 489 developments not available from the above sources mainly prolong historical trends as 490 quantified in the models PANTA RHEI and GINFORS until 2030. They have translated into 491 EXIOBASE compatible observations and classifications (see also above). 
494

495

496

497

498

499

25. Galli, A. et al. Integrating Ecological, Carbon and Water Footprint: Defining the „Footprint Family“ and its Application in Tracking Human Pressure on the Planet. One Planet Economy Network (OPEN: EU) (2011).

26. Bringezu, S. et al. Multi-scale Governance of Sustainable Natural Resource Use Challenges and Opportunities for Monitoring and Institutional Development at the National and Global Level. Sustainability 8, 778; doi: 10.3390/su8080778, (2016).

27. Wiebe, K. S., Lutz, C., Bruckner, M. \& Giljum, S. The Global Resource Accounting Model (GRAM), in: Murray, J., Lenzen, M. (eds.): The Sustainability Practicioner's Guide to Multi-Regional Input-Output Analysis. Common Ground, Champaign, Illinois, 79-87 (2013).

28. Stadler K. et al. EXIOBASE 3: Developing a Time Series of Detailed Environmentally Extended Multi-Regional Input-Output Tables. Journal of Industrial Ecology 22(3), 502515 (2018).

29. Wood, R. et al. Global Sustainability Accounting - Developing EXIOBASE for MultiRegional Footprint Analysis. Sustainability 7(1), 138-163; doi: 10.3390/su7010138, (2015).

30. Riahi, K. et al. The Shared Socioeconomic Pathways and their energy, land use, and greenhouse gas emissions implications: An overview. Global Environmental Change 42, 153-168 (2017).

31. O'Neill, B. C. et al. (2017): The roads ahead: Narratives for shared socioeconomic pathways describing world futures in the 21st century. Global Environmental Change $\mathbf{4 2}$, 169-180 (2017). 
32. United Nations, Department of Economic and Social Affairs, Population Division. World Population Prospects 2019: Volume I: Comprehensive Tables. (2019).

33. Dellink, R., Chateau, J., Lanzi, E. \& Magné, B. (2017): Long-term economic growth projections in the Shared Socio-economic Pathways. Global Environmental Change 42, 200-214 (2017).

34. Lutz, C., Becker, L., Ulrich, P. \& Distelkamp, M. Sozioökonomische Szenarien als Grundlage der Vulnerabilitätsanalysen für Deutschland - Teilbericht des Vorhabens „Politikinstrumente zur Klimaanpassung“. Climate Change 25/2019, Dessau-Roßlau. (2019).

35. Ulrich, P. \& Lehr, U. Economic effects of an E-mobility scenario - input structure and energy consumption. Economic Systems Research 32, 84-97 (2019).

36. Lutz, C. \& Lehr, U. Economic impacts of the energy transition. In: Soytas, U, Sari, R. (eds.): Routledge Handbook of Energy Economics. Routledge, London, New York, 95(2018).

38. Wiebe, K. S., Gandy, S. \& Lutz, C. Policies and Consumption-Based Carbon Emissions

37. Ahlert, G., Meyer, M. \& Distelkamp, M. Foresight and scenarios: modelling practices and resource nexus assessment. In: Bleischwitz, R., Hoff, H., Spataru, C., Van der Voet, E. \& VanDeveer, S.D. (eds.): Routledge Handbook of the Resource Nexus, 207-219 from a Top-Down and a Bottom-Up Perspective. Low Carbon Economy 7, 21-35 (2016).

39. Schaldach, R. et al. An integrated approach to modelling land-use change on continental and global scales. Environmental Modelling \& Software 26(8), 1041-1051 (2011).

40. Schaldach, R., Koch, J., Aus der Beek, T., Kynast, E. \& Flörke, M. Current and future irrigation water requirements in pan-Europe: An integrated analysis of socio-economic and climate scenarios. Global and Planetary Change 94-95, 33-45 (2012).

41. Defourny, P. et al. Land cover CCI. Product User Guide Version, 2 (2012). 
42. CCI. (C) ESA Climate Change Initiative - Land Cover led by UCLouvain (2017), accessible under http://maps.elie.ucl.ac.be/CCI/viewer/download.php, downloaded 2017, (2017).

43. Bondeau, A. et al. Modelling the role of agriculture for the 20th century global terrestrial carbon balance. Global Change Biology 13(3), 679-706 (2007).

44. You, L., Wood, S., Wood-Sichra, U., \& Wu, W. Generating global crop distribution maps: From census to grid. Agricultural Systems 127, 53-60 (2014).

45. IFPRI and IIASA. International Food Policy Research Institute (IFPRI). International Institute for Applied Systems Analysis (IIASA), 2016, "Global Spatially-Disaggregated Crop Production Statistics Data for 2005 Version 3.2", https://doi.org/10.7910/DVN/DHXBJX, Harvard Dataverse, V9 (2016).

46. IFPRI. International Food Policy Research Institute, 2019, "Global SpatiallyDisaggregated Crop Production Statistics Data for 2010 Version 2.0”, https://doi.org/10.7910/DVN/PRFF8V, Harvard Dataverse, V4 (2019).

47. Potapov P. et al. Mapping the World's Intact Forest Landscapes by Remote Sensing. Ecology and Society 13(2), 51 (2008).

48. Jenkins, C. N., Pimm, S. L.., Joppac, L. N. Global patterns of terrestrial vertebrate diversity and conservation. PNAS: E2602-E2610. https://doi.org/10.1073/pnas.1302251110, (2013).

49. Paracchini, M. L. High Nature Value Farmland in Europe. An estimate of the distribution patterns on the basis of land cover and biodiversity data. JRC Scientific and Technical Reports. European Communities, Luxembourg. (2008).

50. FAO/IIASA/ISRIC/ISS-CAS/JRC. Harmonized World Soil Database (version 1.0). FAO, Rome, Italy and IIASA, Laxenburg, Austria, (2008).

51. Lehner, B. and Döll, P. Development and validation of a global database of lakes, reservoirs and wetlands. Journal of Hydrology 296(1-4), 1-22 (2004). 
52. UNEP-WCMC. User Manual for the World Database on Protected Areas and world database on other effective area-based conservation measures:1.6. UNEP-WCMC: Cambridge, UK. (2019).

53. Smith, M. Irrigation and Drainage Pap. 46, CROPWAT - A Computer Program for Irrigation Planning and Management. (Food and Agric. Org. of the U. N, Rome, Italy, 1992).

54. Hempel, S., K. Frieler, L. Warszawski, J. Schewe, and F. Piontek. A trend-preserving bias correction - The ISI-MIP approach. Earth Syst. Dyn. 4(2), 219-236 (2013).

55. Raskin, P., Gleick, P., Kirshen, P., Pontius, G., \& Strzepek, K. Comprehensive assessment of the freshwater resources of the world. Stockholm, Sweden: Stockholm Environment Institute, p. 77, (1997).

56. Eisner, S. Comprehensive Evaluation of the WaterGAP3 Model across Climatic, Physiographic, and Anthropogenic Gradients. PhD thesis, Univ. Kassel (2016).

57. Eisner, S. et al. An ensemble analysis of climate change impacts on streamflow seasonality across 11 large river basins. Clim. Change 141, 401-417 (2017).

58. Schneider, C., Flörke, M., Eisner, S. \& Voss, F. Large scale modelling of bankfull flow: an example for Europe. J. Hydrol. 408, 235-245 (2011).

59. Verzano, K. et al. Modeling variable river flow velocity on continental scale: current situation and climate change impacts in Europe. J. Hydrol. 424-425, 238-251 (2012).

60. Flörke, M. et al. Domestic and industrial water uses of the past 60 years as a mirror of socio-economic development: A global simulation study. Global Environmental Change 23(1), 144-156 (2013).

61. Hanasaki, N., Yoshikawa, S., Pokhrel, Y., \& Kanae, S. A quantitative investigation of the thresholds for two conventional water scarcity indicators using a state-of-the-art global hydrological model with human activities. Water Resources Research 54(10), 8279-8294 (2018). 
595 Acknowledgements. The work was funded by the German Ministry for Education and 596 Research (BMBF) within the framework of the SYMOBIO project (no. 031 B0281A).

\section{Author Contributions}

598 Stefan Bringezu designed the approach, coordinated the research and contributed to

599 methodological development of FP calculations. Martin Distelkamp and Christian Lutz

600 conducted MRIO analysis, calculated biomass material FP, analyzed climate FP and socio-

601 economic performance. Florian Wimmer and Rüdiger Schaldach conducted land use

602 modelling and water FP calculations. Klaus Hennenberg and Hannes Böttcher attributed land

603 FP and land transformation to land use categories. Vincent Egenolf calculated the forest

604 material FP.

605 Competing Interests

606 Authors declare no conflict of interest. 
a) Agriculture material footprint

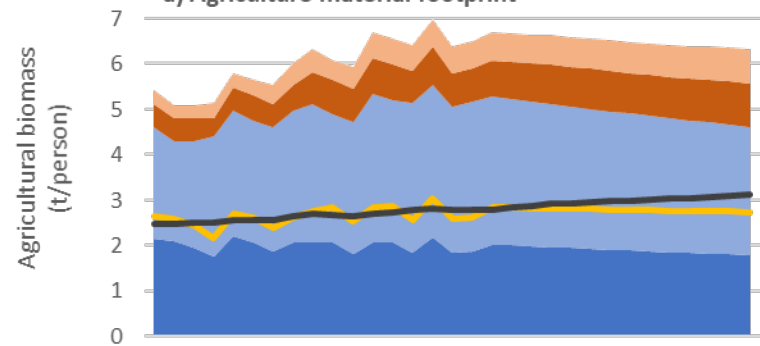

b) Forestry material footprint

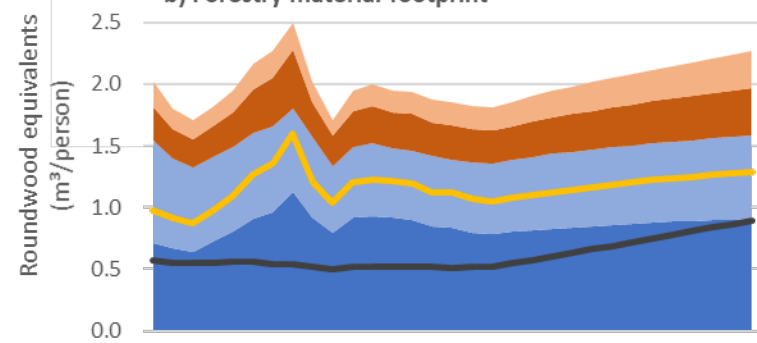

c) Land footprint

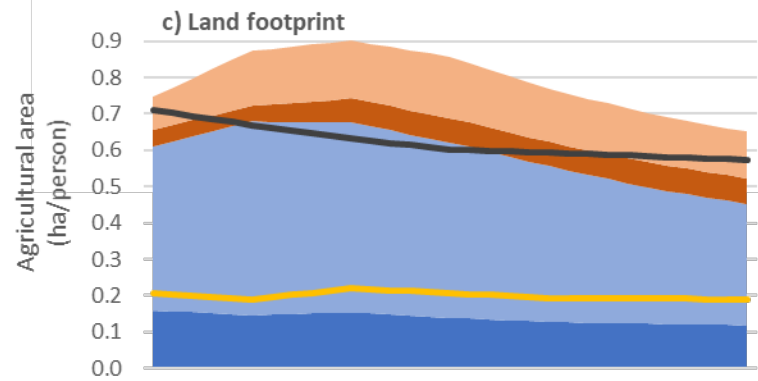

d) Water footprint

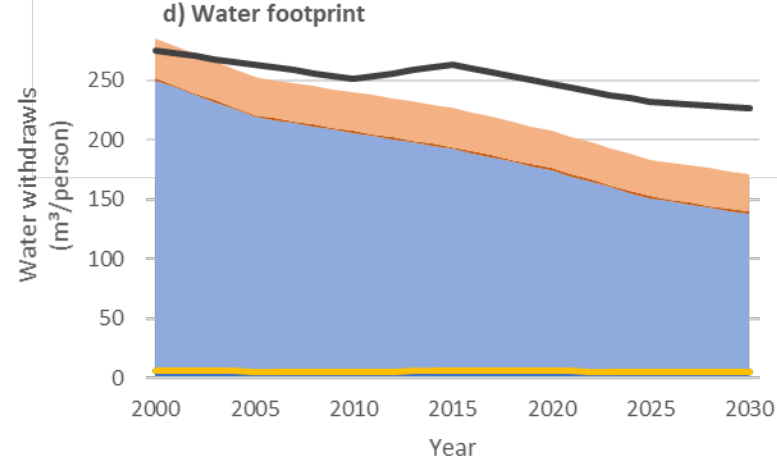

e) Climate footprint

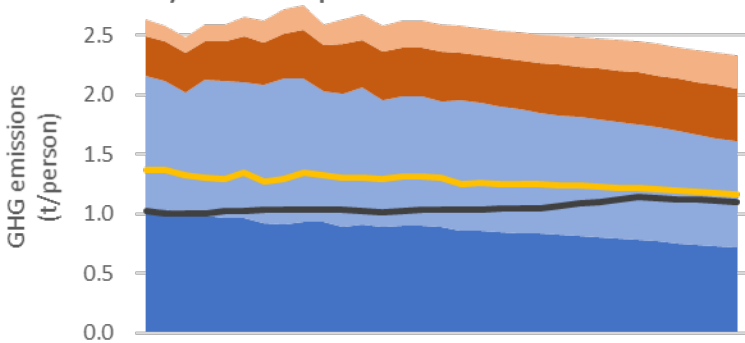

f) Value added footprint

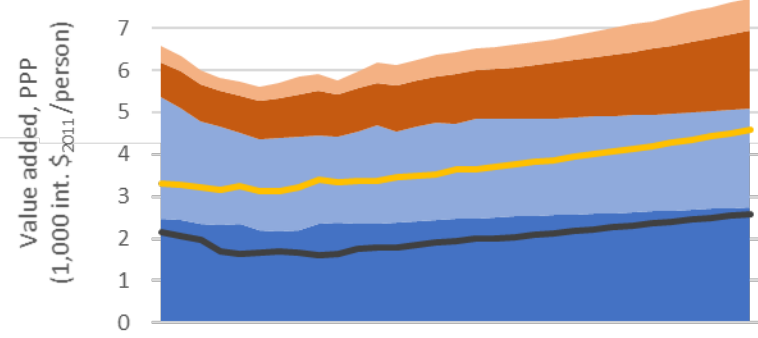

g) Employment footprint

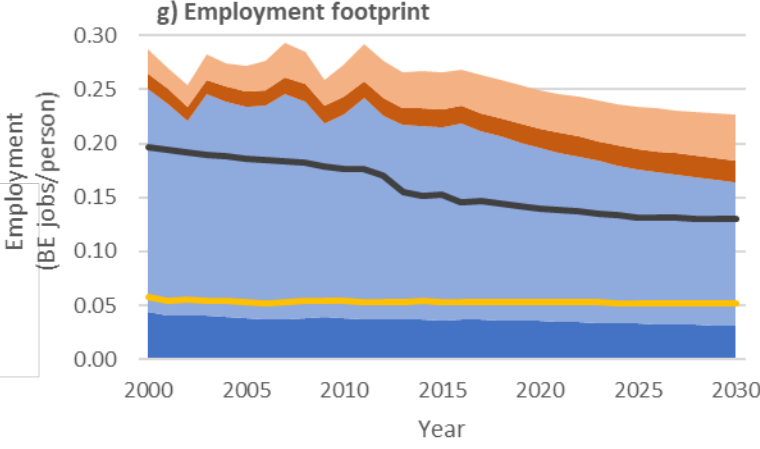

Export use of imports

Export use of domestic production

Domestic use of imports

Domestic use of domestic production

Domestic production

World average

608

609 Fig. 1 Trends of key environmental and socio-economic footprints (FP) of the German

610 bioeconomy: (a) Agriculture biomass FP, (b) Forest biomass FP, (c) Agriculture land FP, (d)

611 Water FP, (e) Climate FP, $(f)$ value added FP and $(g)$ employment FP. PPP = Purchase

\section{Power Parity.}

613 
a) Land footprint for consumption

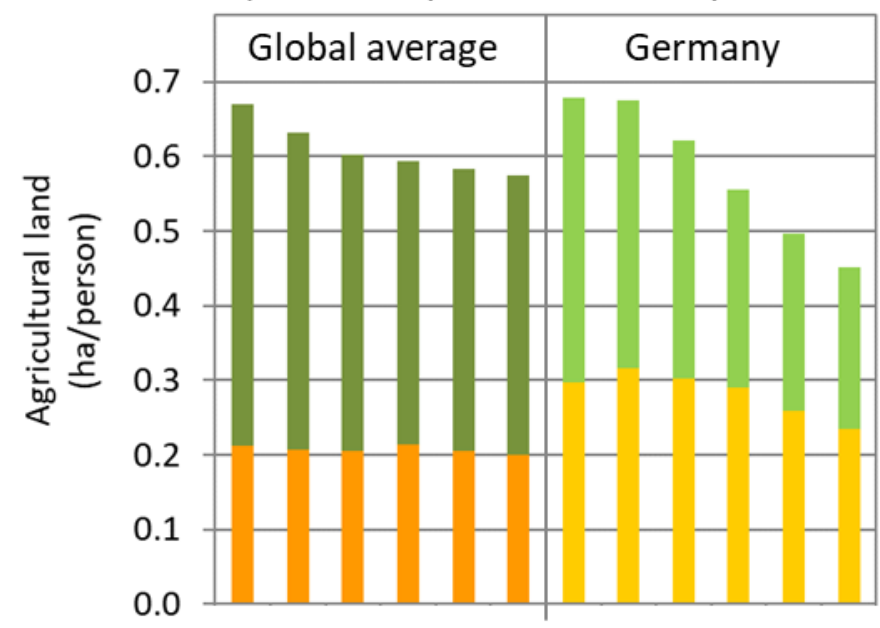

b) Land conversion due to

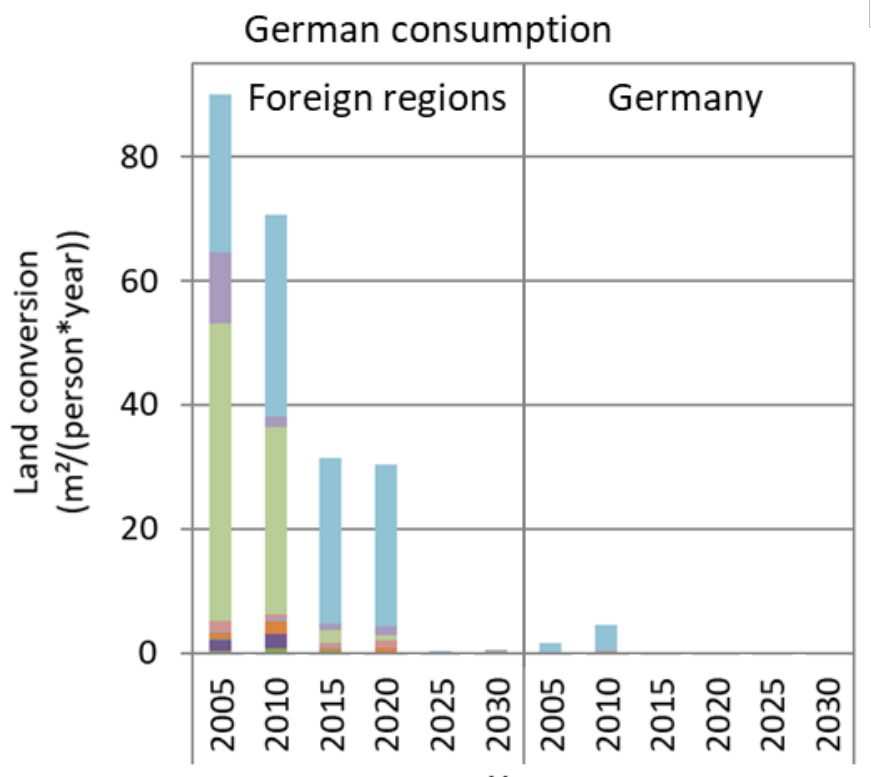

Year
- Grassland (Germany)

- Cropland (Germany)

- Grassland (global)

- Cropland (global)

Land transformed:

- Used grassland

- Unused grassland

Forest

- Wetland

- Peatland

- Other biodiverse land

- Biodiverse grassland

- Biodiverse forest

a Primary forest

c) Land conversion due to global consumption

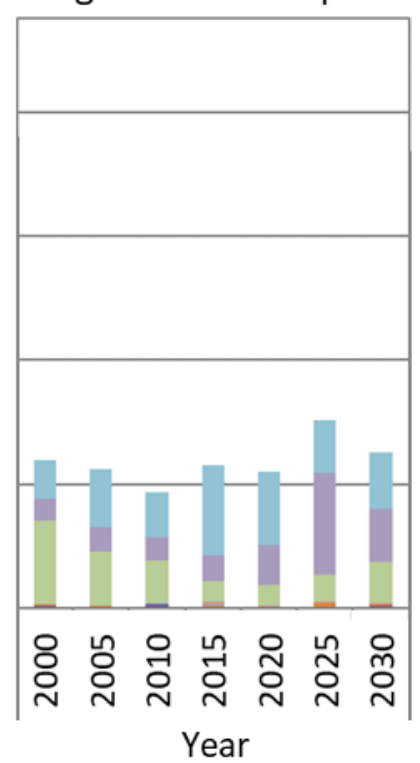

Year

614

616 Fig. 2. Agriculture land footprint of the German bioeconomy: (a) Trends of grassland and

617 cropland for global and domestic consumption, (b) land use change induced by German

618 consumption of agricultural biomass, (c) global land use change induced by agriculture. 


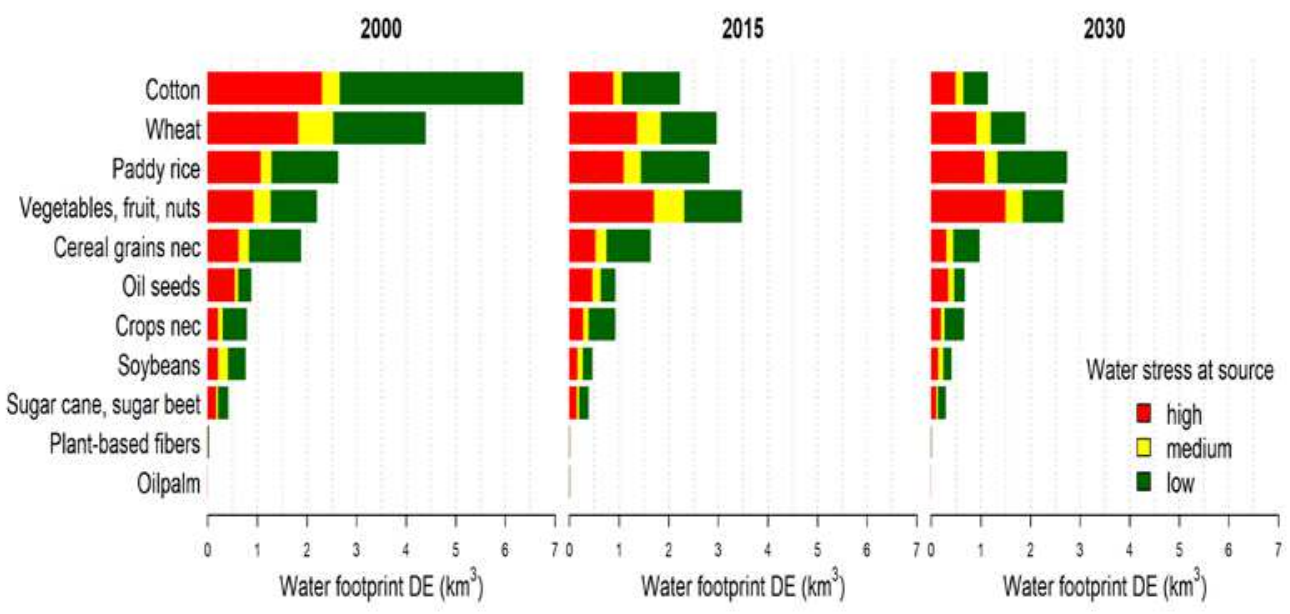

624

625 Fig. 3. Water footprint of annual consumption of agricultural goods in Germany by primary

626 crop class, categorized by water stress level. 


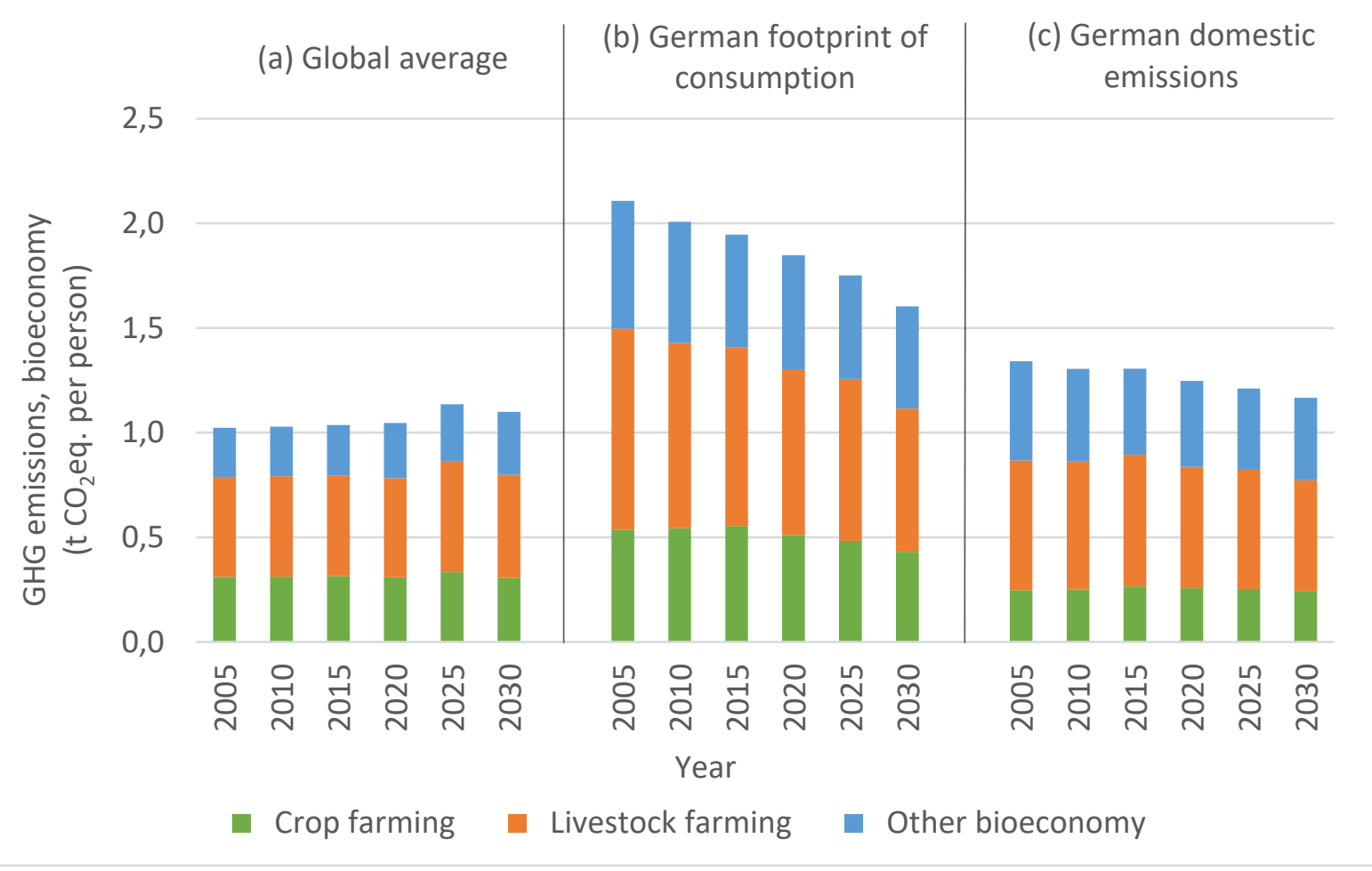

631 Fig. 4. Bioeconomy-based GHG emissions: (a) global average, (b) climate footprint of

632 consumption of Germany, and (c) emissions from German territory. Other BE: forestry,

633 fisheries, manufacturing of biotic resources (e.g. food \& beverages, bio-based chemicals),

634 wood-based construction, bioenergy, restaurants 

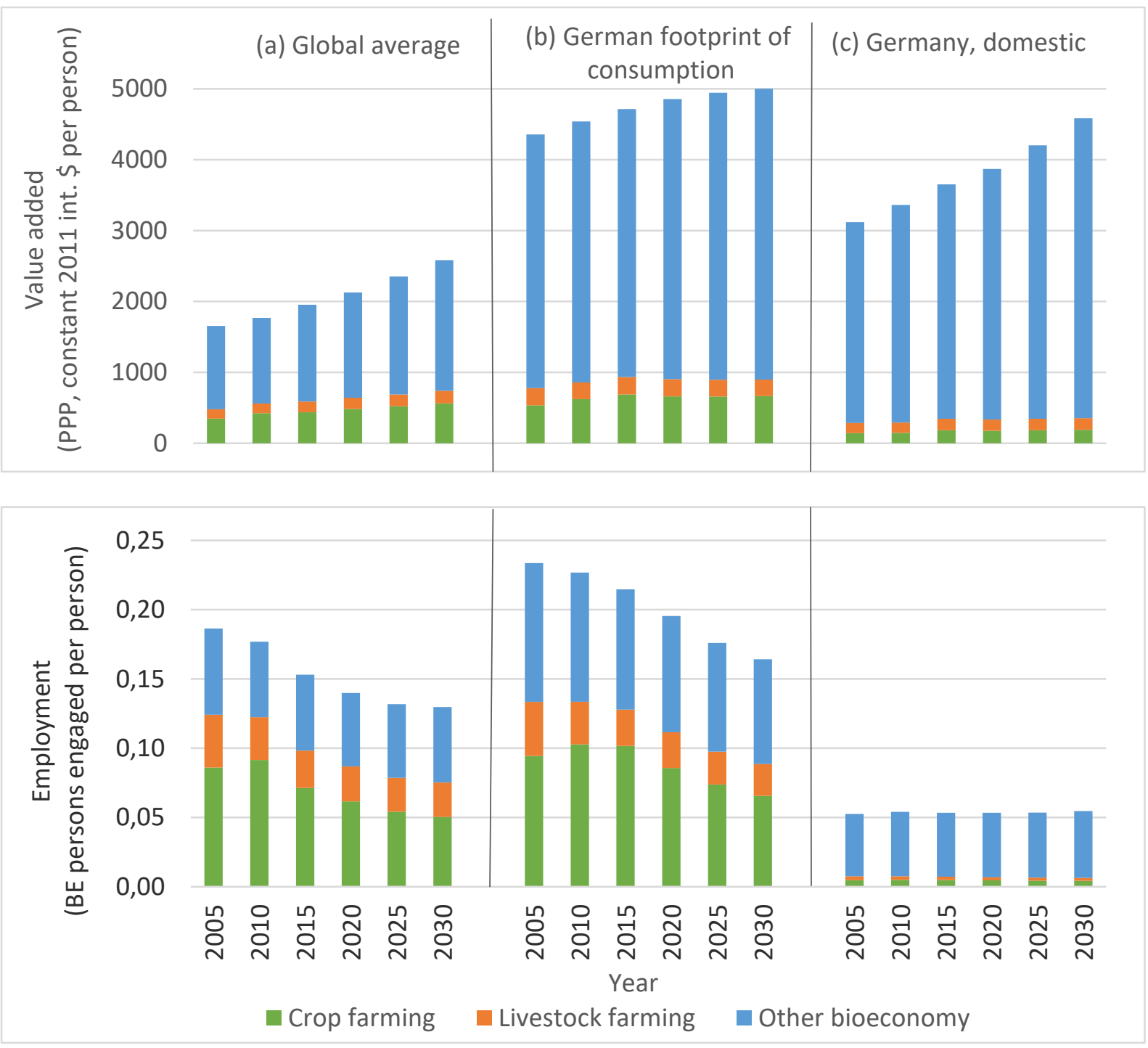

642 Fig. 5. Bioeconomy-based value added and employment: (a) global average, (b) footprint of

643 consumption of Germany, and (c) socioeconomic impact within Germany. Other BE: forestry,

644 fisheries, manufacturing of biotic resources (e.g. food \& beverages, bio-based chemicals), wood-based construction, bioenergy, restaurants 


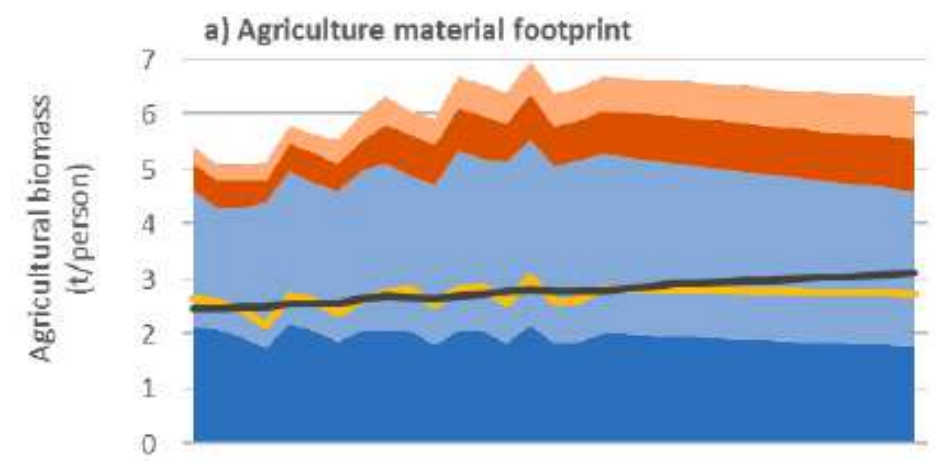

b) Forestry material footprint
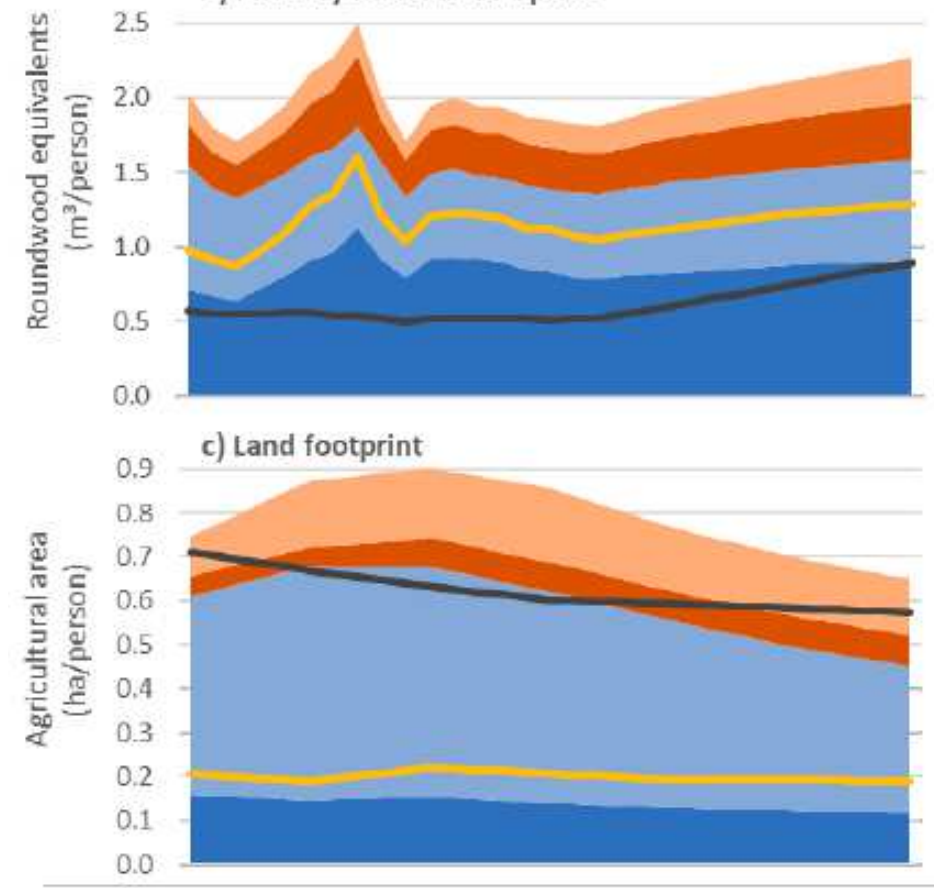

d) Water footprint

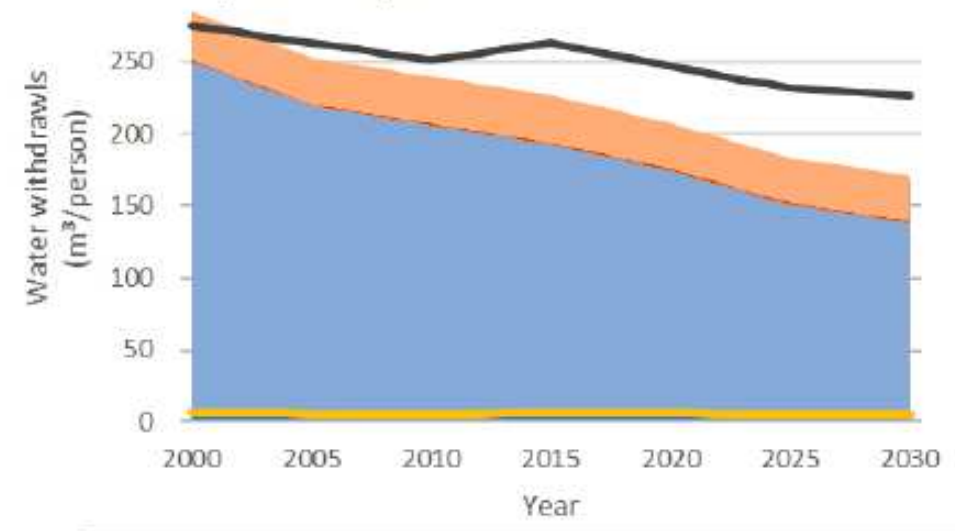

e) Climate footprint

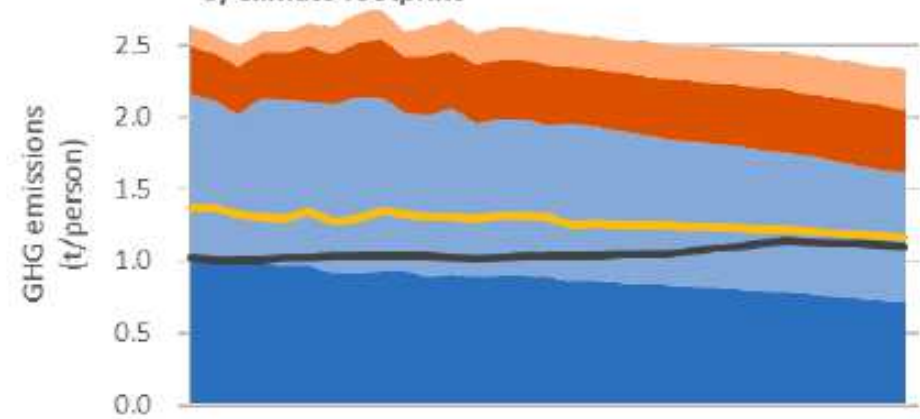

f) Value added footprint

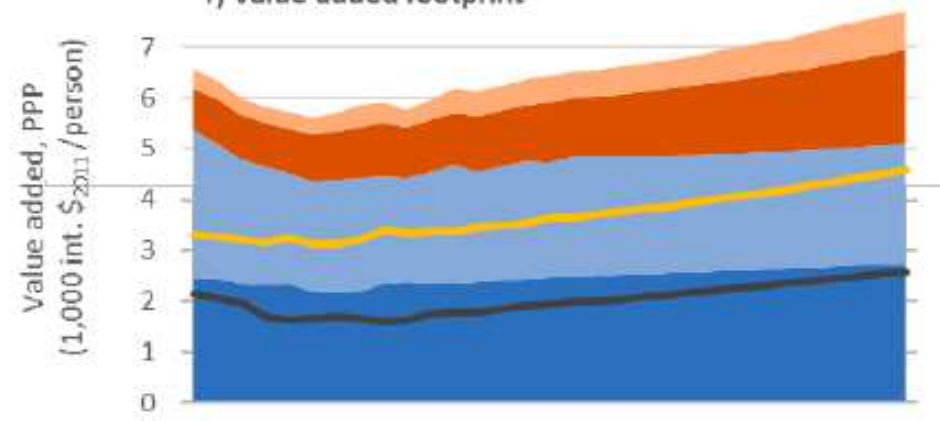

g) Employment footprint

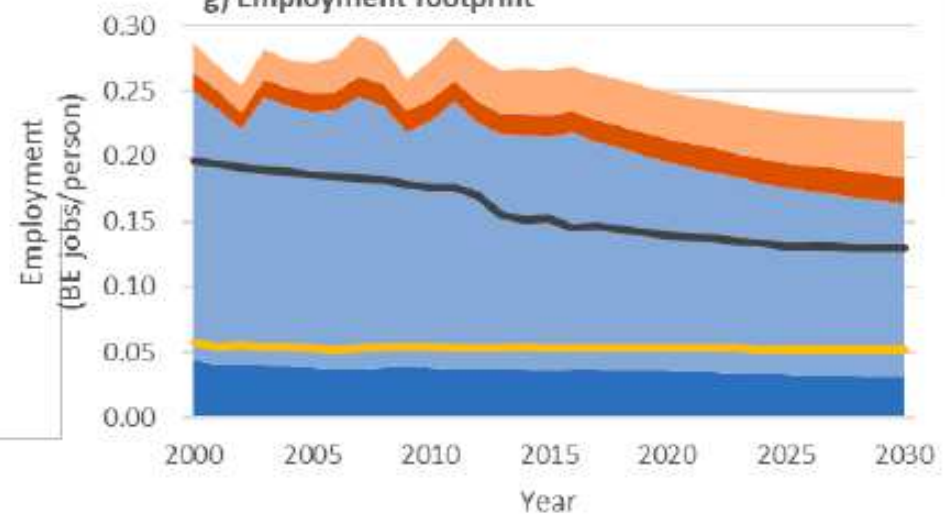

Export use of imports

Export use of domestic production

Domestic use of imports

Domestic use of domestic production

Domestic production

World average

\section{Figure 1}

Trends of key environmental and socio-economic footprints (FP) of the German bioeconomy: (a) Agriculture biomass FP, (b) Forest biomass FP, (c) Agriculture land FP, (d) Water FP, (e) Climate FP, (f) value added FP and (g) employment FP. PPP = Purchase Power Parity. 
a) Land footprint for consumption

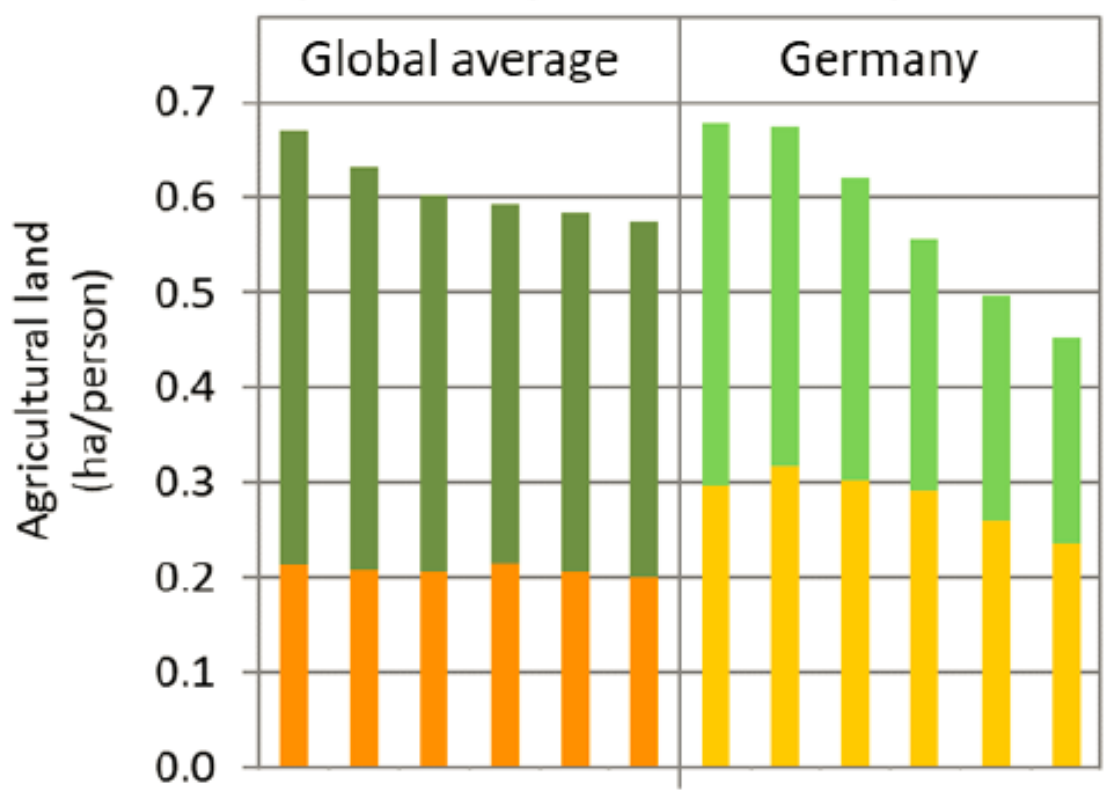

b) Land conversion due to

German consumption

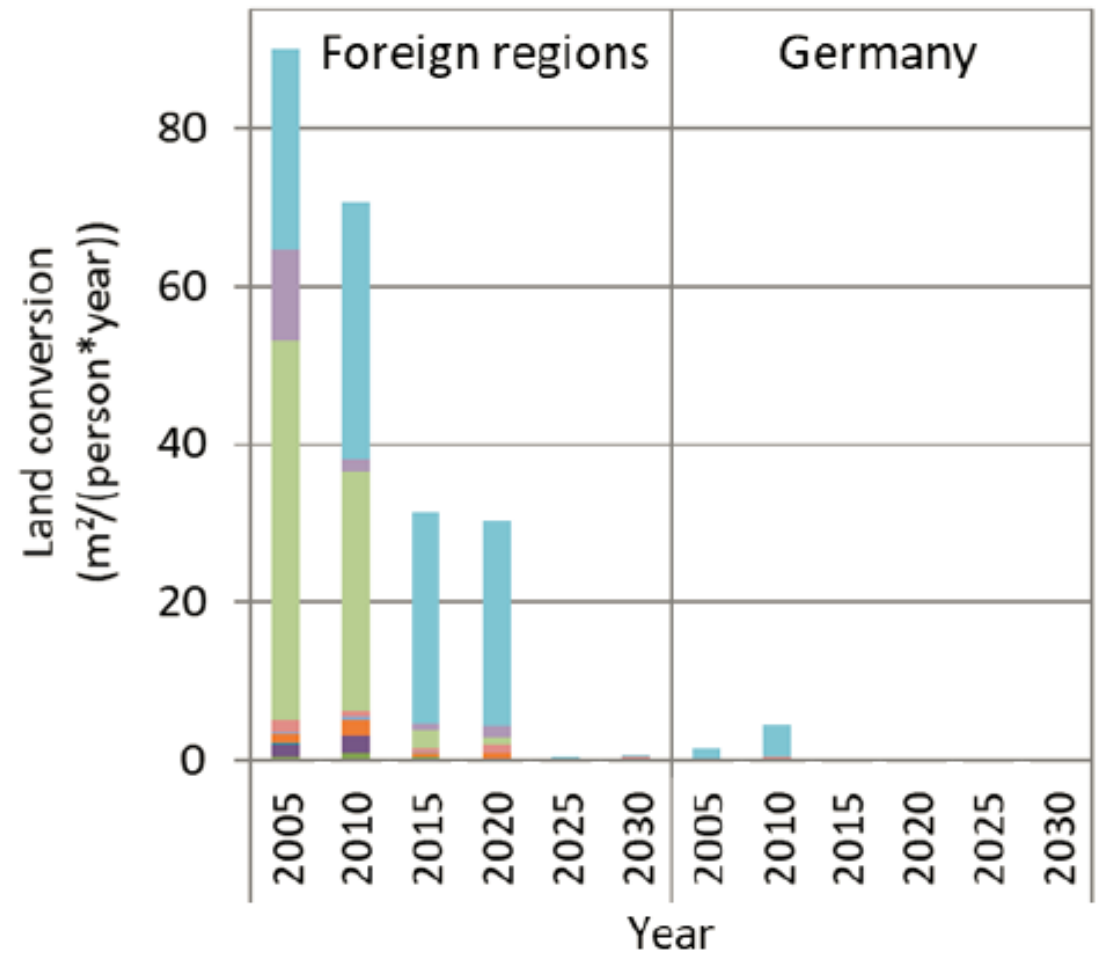

- Grassland (Germany)

Cropland (Germany)

- Grassland (global)

- Cropland (global)

Land transformed:

- Used grassland

Unused grassland

- Forest

Wetland

Peatland

- Other biodiverse land

Biodiverse grassland

- Biodiverse forest

Primary forest

c) Land conversion due to global consumption

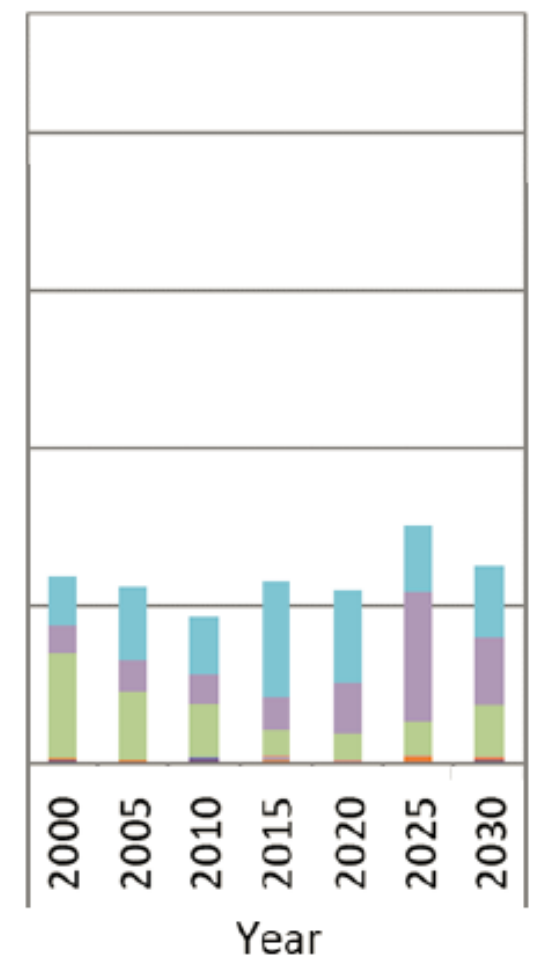

\section{Figure 2}

Agriculture land footprint of the German bioeconomy: (a) Trends of grassland and cropland for global and domestic consumption, (b) land use change induced by German consumption of agricultural biomass, (c) global land use change induced by agriculture. 


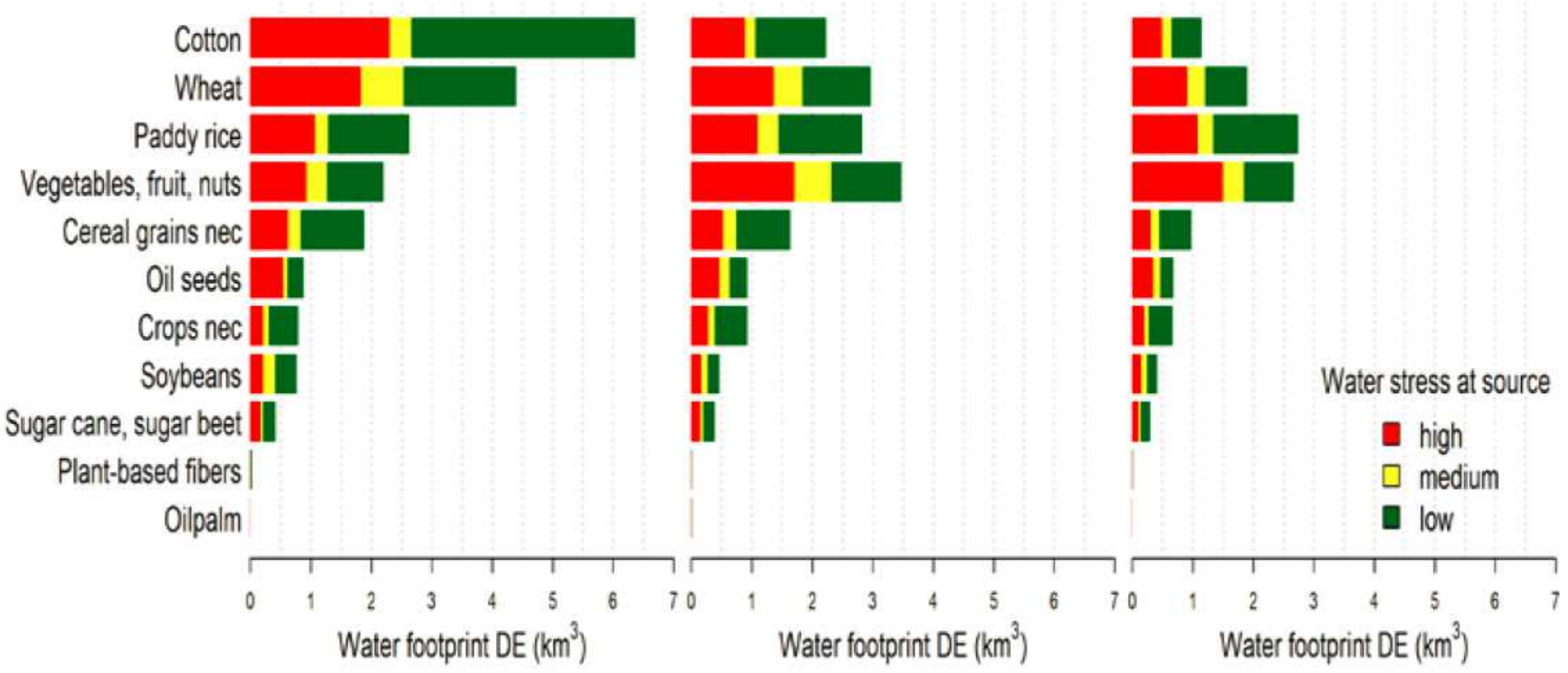

\section{Figure 3}

Water footprint of annual consumption of agricultural goods in Germany by primary crop class, categorized by water stress level.

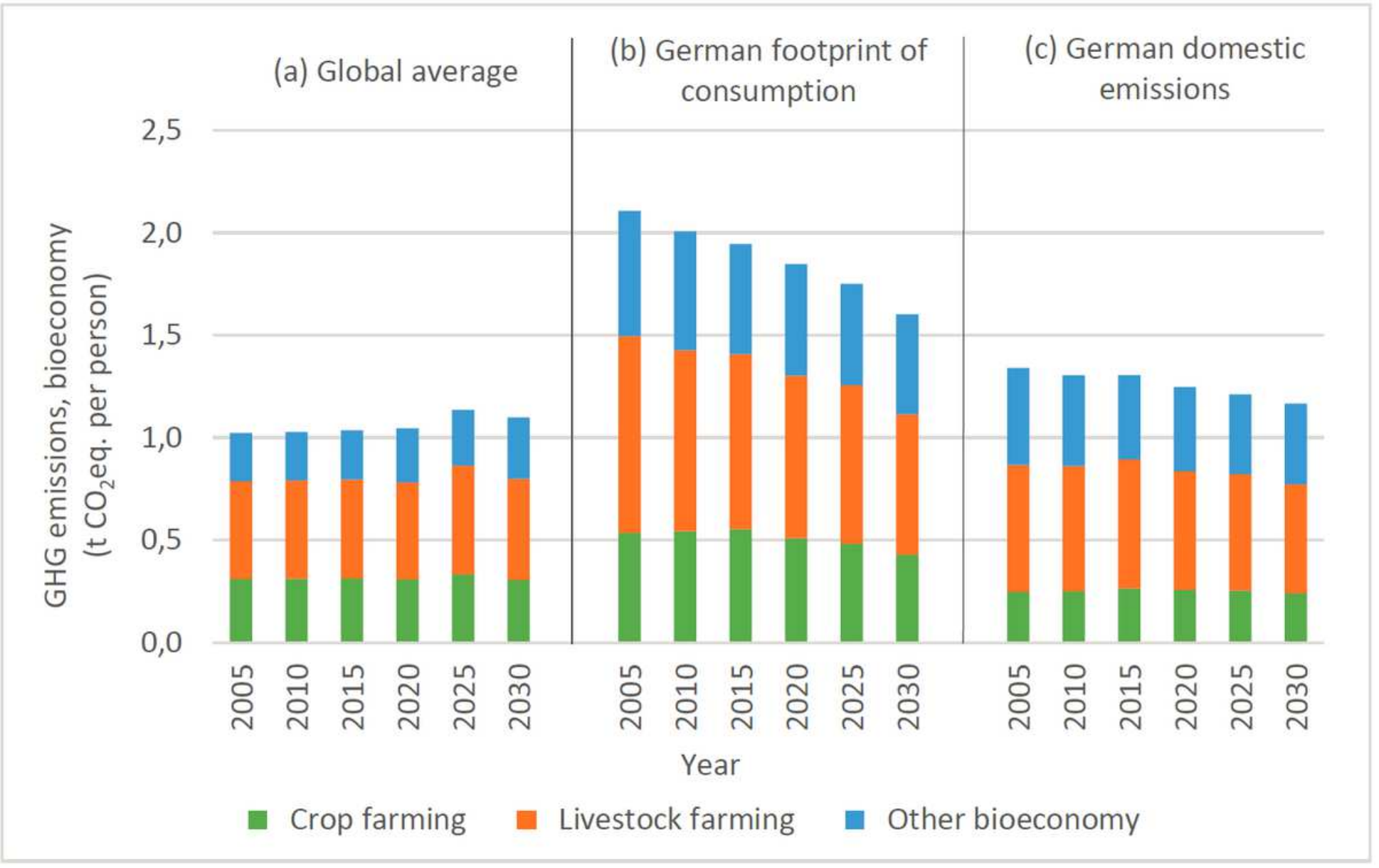


Figure 4

Bioeconomy-based GHG emissions: (a) global average, (b) climate footprint of consumption of Germany, and (c) emissions from German territory. Other BE: forestry, fisheries, manufacturing of biotic resources (e.g. food \& beverages, bio-based chemicals), wood-based construction, bioenergy, restaurants
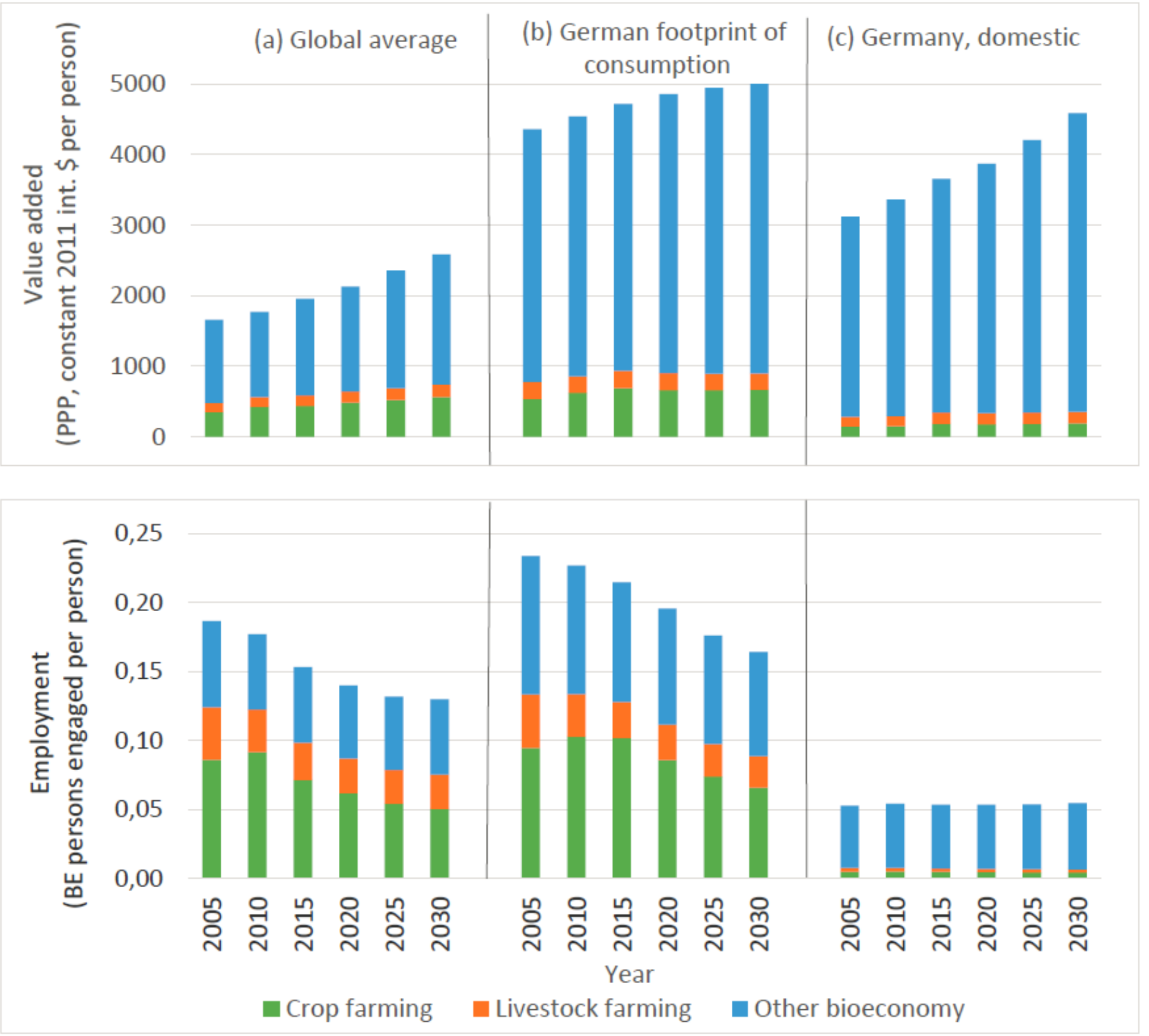

Figure 5

Bioeconomy-based value added and employment: (a) global average, (b) footprint of consumption of Germany, and (c) socioeconomic impact within Germany. Other BE: forestry, fisheries, manufacturing of biotic resources (e.g. food \& beverages, bio-based chemicals), wood-based construction, bioenergy, restaurants 